\title{
Legal Guarantees for the Protection of the Labor Rights of Persons with Disabilities in Ukraine
}

\author{
Oksana Triukhan $^{1}$, Inna Chumachenko ${ }^{2}$, Olena Zanko ${ }^{3}$, Hodovaniuk Andrii ${ }^{4} \&$ Viktoriia Formaniuk ${ }^{5}$ \\ ${ }^{1}$ Department of Labour Law and Social Security Law, National University "Odesa Law Academy”, Odesa, \\ Ukraine \\ ${ }^{2}$ Department of Agricultural, Land and Environmental Law, National University “Odesa Law Academy”, Odesa, \\ Ukraine \\ ${ }^{3}$ Department of Foreign Languages, National University “Odesa Law Academy”, Odesa, Ukraine \\ ${ }^{4}$ Department of Agricultural, Land and Environmental Law, National University “Odesa Law Academy”, Odesa, \\ Ukraine \\ ${ }^{5}$ Department of International and European Law, National University “Odesa Law Academy”, Odesa, Ukraine \\ Correspondence: Oksana Triukhan, National University "Odesa Law Academy", Odesa, Ukraine. E-mail: \\ triuhanoksana2@gmail.com
}

Received: April 17, 2020

Accepted: May 16, $2020 \quad$ Online Published: May 25, 2020

doi:10.5539/jpl.v13n2p164

URL: https://doi.org/10.5539/jpl.v13n2p164

\begin{abstract}
The content of universal and European regional international instruments on protection of labor rights of persons with disabilities is analyzed in the paper. The conclusion is made that Ukraine should take into account the positive foreign experience of the leading countries in the field of state policy of support for persons with disabilities and its implementation. It is justified that the world experience in the field of employment for persons with disabilities will facilitate the practical implementation not only of government programs but also of measures to protect the interests of persons with disabilities. A number of scholarly publications on the subject have been investigated, containing suggestions by scientists to improve promising labor law regarding the manifestations of discrimination on the basis of disability in the field of work. Some theoretically sound recommendations for improving the legal regulation of the protection of the labor rights of persons with disabilities and ensuring that they fulfill their responsibilities were developed. General conclusions have been drawn that the problem of the legal mechanism for the protection of the labor rights of persons with disabilities needs reforming and improvement. Some proposals for improving the legal regulation in this field were given.
\end{abstract}

Keywords: persons with disabilities, labor rights, employment, guarantees, discrimination, protection

\section{Introduction}

According to UNESCO, there are over one billion people with disabilities in the world, of whom between 110-190 million experience very significant difficulties. This corresponds to about $15 \%$ of the world's population and is higher than previous World Health Organization (WHO) estimates, which date from the 1970s and suggested a figure of around $10 \% .{ }^{1}$ Most of persons with disabilities cannot live fully because of social and physical barriers. That is why the policy of each socially oriented state determines as one of its directions the rehabilitation of the people with disabilities, giving them the opportunity to work, satisfy their cultural interests.

According to the United Nations Development Program, $80 \%$ of people with disabilities live in developing countries. According to World Bank, $20 \%$ of the world's poorest people are people with disabilities. Statistics show a steady increase in these numbers. The reasons include emergence of new diseases and other causes of impairment, increasing life span and numbers of elderly persons, increasing in the number of disabled children over the next 30 years, due to malnutrition, diseases, child labor and other causes, armed conflict and violence ${ }^{2}$.

\footnotetext{
Kasinskaite-Buddeberg I. (2011). Accessibility policies and the work of UNESCO [online] Retrieved from: https://www.european-agency.org/sites/default/files/UNESCO-Irmgarda-Kasinskaite-Buddeberg.pdf. [Accessed 10 Apr. 2020].

2 Disability Statistics: Information, Charts, Graphs and Tables. (2020). [online] Retrieved from: https://www.disabled-world.com/disability/statistics/ [Accessed 10 Apr. 2020].
} 
The problems of people with disabilities have long gone unnoticed by the international community. For a long time, the protection of the rights of persons with disabilities was regarded as a national issue, and the states resolved the problems of persons with disabilities on the basis of the priorities of social policy, financial opportunities, and the attitude of the society towards their representatives with certain health disorders. For a long time, disability was not regarded as a human rights issue, but was largely regarded as a matter of health care and rehabilitation. The international community has made tremendous efforts to address the complex problem of the socially vulnerable situation of people with disabilities in society. International human rights treaties, developed in the twentieth century, did not take into account the special needs of persons with disabilities and thus could not fully protect their rights, and the guidelines contained in special international instruments on social protection of persons with disabilities did not guarantee persons with disabilities full participation in society.

Recently, the priorities of international cooperation on disability have changed a lot. However, while there are changes in the international regulation of the legal status of persons with disabilities, the problem of the promotion and protection of the rights of this socially vulnerable population is no longer relevant, as international legal and national aspects of the protection of the rights of persons with disabilities, including the legal status of persons with disabilities in society, needs rethinking and re-evaluating in the light of the global changes that are taking place in the world.

Despite the existence of some scientific works on the protection of the labor rights of persons with disabilities, we believe that the problem has not been fully studied and investigated, and some problems in this area, such as the issues of employment and dismissal of persons with disabilities, remain unresolved.

\section{Material Studied, Area Descriptions, Methods}

The purpose of this study is to identify theoretical and regulatory provisions related to international legal and national instruments for the protection of labor rights of persons with disabilities, to analyze foreign approaches to the legislative regulation of protection of labor rights of persons with disabilities in the workplace, to make some recommendations and proposals to prevent unlawful dismissal and to find out the best ways to reform labor legislation and protect workers who are exposed to workplace discrimination.

To achieve the purpose mentioned above, general and special scientific research methods are used in the study. As material for study were used social relations arising in the sphere of employment and dismissal of persons with disabilities. Legal nature of the labor rights of persons with disabilities was considered on the basis of scientific literature analysis. The methodological basis for the study was a dialectical method which allowed reviewing the issues in their development and interconnection.

\section{Results and Discussion.}

\subsection{Protection of Labor Rights of Persons with Disabilities: International Legal Aspect}

Protection of the rights of persons with disabilities, as well as realization of those rights, is a pressing problem for the international community. Recently, the priorities of international cooperation on disability have changed significantly. However, while there are changes in the international regulation of the legal status of persons with disabilities, the problem of protection of the rights of this socially vulnerable group of people does not cease to be relevant ${ }^{3}$.

Talking about international level of protection of persons with disabilities, we should mention that most international legal instruments on the protection of the rights of persons with disabilities are approved by the main bodies and specialized agencies of the United Nations. These documents form the basis of international cooperation between states on disability issues, serve as a benchmark for national legislation, a tool for protecting this socially vulnerable population, as an impetus for the development of regional rulemaking.

It should be noted that the rights of persons with disabilities have long been the subject of close attention by the United Nations and other international organizations. The Universal Declaration of Human Rights, adopted on December 10, 1948 by the General Assembly of the United Nations, remains the main normative act at the global level. The Universal Declaration established the fundamental, inalienable rights of persons with disabilities, including in the workplace ${ }^{4}$. It is noteworthy that the Declaration of Social Progress and

\footnotetext{
${ }^{3}$ Saunders H. (2019). The Invisible Law of Visible Difference: Disfigurement in the Workplace. Industrial Law Journal, 48(4), p. 487-514. Doi 10.1093/indlaw/dwy019

4 United Nations. (1948). Universal Declaration of Human Rights. [online] Retrieved from: https://www.un.org/en/universal-declaration-human-rights/. [Accessed 10 Apr. 2020].
} 
Development was adopted on December 11, 1969, which stated in Article XI the principle of protection of the rights and welfare of children, the elderly and people with disabilities; ensuring protection for people with physical and mental disabilities ${ }^{5}$.

On December 9, 1975, the United Nations General Assembly adopted the Declaration on the Rights of Disabled Persons. The Declaration on the Rights of Disabled Persons contains provisions designed to respect human dignity, civil and political rights, and protect against discrimination on any grounds ${ }^{6}$. It should be emphasized that a human rights approach to addressing the problems of persons with disabilities was formally recognized for the first time.

In 1980 the World Health Organization adopted International Classification of Impairments, Disabilities and Handicaps. The document stipulates that "disability is any restriction or lack (resulting from an impainnent) of ability to perform an activity in the manner or within the range considered normal for a human being"?

In addition, on December 3, 1982, the United Nations General Assembly adopted the first the World Programme of Action concerning Disabled Persons. This Program was the first internationally accepted attempt to address the issue of disability on both sides - the development and protection of human rights ${ }^{8}$. It should also be noted that the World Programme of Action concerning Disabled Persons served as the basis for the development of the Standard Rules on the Equalization of Opportunities for Persons with Disabilities (hereinafter - Standard Rules). Standard Rules were adopted in 1993 by the United Nations General Assembly. As the name of the document implies, the primary purpose of the Standard Rules is to create an accessible environment for persons with disabilities, ensuring that men and women with disabilities as members of society have the same rights and responsibilities as other persons. The basic idea behind the Standard Rules is that the primary responsibility for addressing the problems of persons with disabilities lies with the state?

Another instrument that has played an important role in the development of international cooperation on the rights of persons with disabilities is the Convention on the Rights of Persons with Disabilities and the Optional Protocol thereto (hereinafter - Convention), adopted by the United Nations General Assembly on December 13, 2006 and entered into force on May 3, 2008. The Convention is the first international legal instrument to prohibit any discrimination on the basis of disability and to declare a guarantee to persons with disabilities equal and effective legal protection against discrimination. In September 2008, Ukraine signed this Convention and the Optional Protocol thereto. This international legal instrument provides the basic standards for the protection of the rights and freedoms of persons with disabilities. The main purpose of the Convention, as enshrined in Article 1 , is to promote, protect and ensure the full and equal enjoyment by persons with disabilities of all human rights and fundamental freedoms ${ }^{10}$.

The right to work for persons with disabilities is an important condition for social integration and independence. The most common form of discrimination is the refusal to provide opportunities to work at all or to work with regard to the capabilities and abilities of persons with disabilities. Unfortunately, unemployment is one of the most significant problems for people with disabilities ${ }^{11}$. It should be acknowledged that the International Labor Organization (hereinafter - ILO) plays an important role in protecting the rights of persons with disabilities. The main objective of the ILO is to increase the opportunities for decent work for all. Based on the analysis of the

\footnotetext{
5 United Nations General Assembly. (1969). Declaration on Social Progress and Development. [online] Retrieved from: https://www.ohchr.org/Documents/ProfessionalInterest/progress.pdf. [Accessed 10 Apr. 2020].

6 United Nations General Assembly. (1975). Declaration on the Rights of Disabled Persons. [online] Retrieved from: https://www.ohchr.org/EN/ProfessionalInterest/Pages/RightsOfDisabledPersons.aspx. [Accessed 10 Apr. 2020].

${ }^{7}$ World Health Organization (1980). International Classification of Impairments, Disabilities and Handicaps. [online] Retrieved from: https://apps.who.int/iris/bitstream/handle/10665/41003/9241541261_eng.pdf;jsessionid=9A3E39C13CC6D0564FAE3176122D770C?sequen ce $=1$. [Accessed 10 Apr. 2020].

${ }^{8}$ History of United Nations and Persons with Disabilities - The World Programme of Action Concerning Disabled Persons. (2020). [online] Retrieved

https://www.un.org/development/desa/disabilities/history-of-united-nations-and-persons-with-disabilities-the-world-programme-of-action-co ncerning-disabled-persons.html. [Accessed 10 Apr. 2020].

${ }^{9}$ United Nations General Assembly. (1993). Standard Rules on the Equalization of Opportunities for Persons with Disabilities. [online] Retrieved

https://www.un.org/development/desa/disabilities/standard-rules-on-the-equalization-of-opportunities-for-persons-with-disabilities.html.

[Accessed 10 Apr. 2020].

${ }^{10}$ United Nations General Assembly. (2006). Convention on the Rights of Persons with Disabilities and the Optional Protocol thereto. [online] Retrieved from: https://www.refworld.org/topic,50ffbce51b1,50ffbce51c9,,0,UNGA,,.html. [Accessed 10 Apr. 2020].

${ }^{11}$ Akpulat A. (2019). The Liability of the Employer to Employ Disabled Employee. Istanbul Hukuk Mecmuasi, 77(2), p.523-553. Doi 10.26650/mecmua.2019.77.2.0003
} 
content of the ILO conventions, there are several areas of focus for the organization's work to protect the rights of persons with disabilities in the workplace. These include the following: ILO Convention No. 37 on Compulsory Disability Insurance for Industrial and Commercial Workers, Professionals, Homeworkers and Home Servants (1933); ILO Convention No. 38 on Compulsory Invalidity Insurance for Workers in Agriculture (1933); ILO Convention No. 48 on the Establishment of a System of International Cooperation for the Safeguarding of Rights Related to Disability Insurance, Old Age and the Loss of a Family Supporter (1935) and others.

Along with the active work of the United Nations in promoting and protecting the rights of persons with disabilities, international organizations in different regions of the world take concrete steps to improve the quality of life of this category of population. Among the Council of Europe's human rights instruments are two complementary treaties - the Convention for the Protection of Human Rights and Fundamental Freedoms (hereinafter - the Convention for the Protection of Human Rights, European Convention) and the European Social Charter (revised). Unfortunately, the Convention for the Protection of Human Rights neglects the specificity of the protection of the rights of persons with disabilities.

It should be noted that on September 14, 2006, one of the main documents of the Council of Europe in the field of human rights - the European Social Charter (revised) of May 3, 1996, which came into force on February 1, 2007, was ratified in Ukraine. The European Social Charter (revised) regulates protection of human rights in those social areas where persons with disabilities face numerous restrictions and discrimination: in the workplace, outside work, general social protection. The European Social Charter (revised) also contains other rules that ensure the interests of persons with disabilities.

In Art. 15 of the European Social Charter (revised) the rights of persons with disabilities to independence, social integration and participation in public life are enshrined. At the present stage, the content of Art. 15 of the Charter is not limited to regulating only the issues of vocational rehabilitation of the persons with disabilities. This article is also aimed at creating conditions for the social integration of people with disabilities, overcoming social isolation, various barriers that prevent people with disabilities from being active participants in public relations.

The Charter also contains other rules that ensure the interests of persons with disabilities. Article 9 (right to vocational guidance) enshrines the obligation of States to establish or maintain services that will help, including persons with disabilities, to address professional choices, taking into account the personal qualities of the worker and his or her professional capabilities.

Recognition of such rights as the right to work (Article 1), the right to reasonable working conditions (Article 2), the right to safe and healthy working conditions (Article 3), the right to reasonable remuneration is relevant for persons with disabilities (Article 4), the right to health care (Article 11), the right to social security (Article 12), the right to social and medical assistance (Article 13), the right to social services (Article 14) ${ }^{12}$.

\subsection{Protection of Labor Rights of Persons with Disabilities under the Legislation of Ukraine}

The Ukrainian legislation has a sufficiently strong legal basis to ensure employment of persons with disabilities. The basic normative acts are the Constitution of Ukraine, the Labor Code of Ukraine and a number of laws and subordinate legislation of Ukraine.

Thus, Art. 43 of the Constitution of Ukraine proclaims the right of everyone to work, which contains the opportunity to earn a living by work, which the person freely chooses or for which he freely agrees. The state, in turn, undertakes to create conditions for citizens to fully exercise their right to work, guarantees equal opportunities in the choice of profession and type of work, implements programs of vocational training, training and retraining of personnel in accordance with social needs.

The issue of employment of persons with disabilities in Ukraine is regulated by the Labor Code of Ukraine, which was adopted during the Soviet Union in 1971. It should be noted that today the Labor Code of Ukraine not only does not meet the requirements of the present, but also can not properly guarantee the protection of employees. It is appropriate to emphasize that the Labor Code of Ukraine in Article 2-1 provides for equality of labor rights of citizens $^{13}$. Thus, the Labor Code of Ukraine, like the Constitution of Ukraine, established the most widespread grounds for discrimination. However, in order to clarify the principle of legal equality in the state and to prohibit

${ }^{12}$ Council of Europe. (1996). European Social Charter (Revised). [online] Retrieved from: https://rm.coe.int/168007cf93. [Accessed 10 May 2020].

${ }^{13}$ Verkhovna Rada of Ukraine. (1971). Labor Code of Ukraine adopted on December 10, 1971. Vidomosti of the Verkhovna Rada of Ukraine. Application to №50. Art. 375. 
discrimination against persons with disabilities, in our opinion, it is necessary to supplement Article 2-1 of the Labor Code of Ukraine with the words "on the grounds of disability". In addition, it should be noted that employment of persons with disabilities is an obligation of the employer, stipulated by a number of legislative norms, in particular Article 172 of the Labor Code of Ukraine.

In Ukraine today there is a rather extensive legislation regulating the issues of employment of persons with disabilities. In particular, it is the Law of Ukraine "On the basics of social protection of persons with disabilities in Ukraine" of March 21, 1991 No. 875-XII, the Law of Ukraine "On the status of war veterans, guarantees of their social protection" of October 22, 1993 No. 3551-XII, the Law of Ukraine "On Compulsory State Social Insurance" of September 23, 1999 No. 1105-XIV, the Law of Ukraine "On Employment of the Population" of July 5, 2012 No. 5067-VI, the Law of Ukraine "On Occupational Safety" of October 14, 1992, the Law of Ukraine "On Leave" of November 15, 1996, the Resolution of the Cabinet of Ministers of Ukraine on Issues of Medical and Social Expertise of December 3, 2009 No. 1317, the Resolution of the Cabinet of Ministers of Ukraine "Some Issues of Implementation of the Laws of Ukraine "On Fundamentals of Social Protection of Persons with Disabilities in Ukraine" and "On Employment of the Population" of January 31, 2007 No. 70, the Order of the Ministry of Health of Ukraine "On Approval of the Instruction on Establishing Disability Groups" of September 05, 2011 No. 561 and a number of other legal acts. However, it should be noted that, unfortunately, these normative legal acts in Ukraine are either inadequately implemented or not implemented at all.

According to Article 2 of the Law of Ukraine "On the basics of social protection of persons with disabilities in Ukraine" of March 21, 1991, a person with a disability is a person with a persistent disorder of body functions, which, when interacting with the external environment, can lead to a limitation of his or her life. That is the reason why the state is obliged to create conditions for the realization of his or her rights on an equal basis with other citizens and to provide his or her social protection ${ }^{14}$.

The right to rehabilitation of persons with disabilities, its structure and constituents, the procedure for implementation are determined by the Law of Ukraine "On Rehabilitation of Persons with Disabilities in Ukraine"of October 6, 2005 No. 2961-IV, as well as by the Resolutions of the Cabinet of Ministers of Ukraine "On Approval of the Regulation on the Individual Program of Rehabilitation of Persons with Disabilities" of May 2, 2007 No. 757, "On Approval of the State Standard Program of Rehabilitation of Persons with Disabilities" of December 8, 2006 No. 1686, etc.

Thus, the Law of Ukraine "On Rehabilitation of Persons with Disabilities in Ukraine" of October 6, 2005 sets out state guarantees for the provision of vocational and labor rehabilitation services to ensure the competitiveness of a person with a disability in the labor market and in their employment arrangements in both ordinary and special created conditions ${ }^{15}$.

The state now has an important task - to create a barrier-free environment that will enhance the social adaptation of persons with disabilities and enable them to take an active part in public life ${ }^{16}$. To achieve that aim, the Government adopted a Resolution of the Cabinet of Ministers of Ukraine "On Amendments to Some Resolutions of the Cabinet of Ministers of Ukraine" of April 10, 2019 No. 310, which regulated the mechanism of financing measures to promote employment of persons with disabilities at the expense of the Social Security Fund for People with Disabilities. Another legislative act on social protection of people with disabilities, improving their access to medicine, education, work, and objects of physical environment, was the Presidential Decree "On Improving the Effectiveness of Measures in the Field of Rights of Persons with Disabilities" of December 3, 2019 №875/2019 ${ }^{17}$. In accordance with the Presidential Decree No. 875/2019 “On Improving the Effectiveness of Measures in the Field of Rights of Persons with Disabilities", conditions will be created for persons with disabilities to guarantee their rights and freedoms, to increase the level of accessibility of social, medical, educational and other services for them.

However, while there are changes in the international regulation of the legal status of persons with disabilities,

\footnotetext{
${ }^{14}$ Verkhovna Rada of Ukraine. (1991). On the basics of social protection for persons with disabilities in Ukraine: Law of Ukraine of March 21, 1991 No. 875-XII. Vidomosti of the Verkhovna Rada of the USSR. 1991. №21. Art.252.]

${ }^{15}$ Verkhovna Rada of Ukraine. (2006). On the rehabilitation of persons with disabilities in Ukraine: Law of Ukraine of October 6, 2005 No. 2961-IV. Vidomosti of the Verkhovna Rada of Ukraine. 2006. №2. Art.36.

${ }^{16}$ Revillard A. (2019). Realizing the Right to Access in France: Between Implementation and Activation. Law\&Society Review, 53(4), p. 950-982. Doi 10.1111/lasr.12434

${ }^{17}$ President of Ukraine. (2019). Decree of the President of Ukraine "On Improving the Effectiveness of Measures in the Field of Rights of Persons with Disabilities" of 03.12.2019 №875 / 2019. [online] Retrieved from: https://www.president.gov.ua/documents/8752019-30781. [Accessed 10 Apr. 2020].
} 
the problem of protection of the rights of this socially vulnerable group of people does not cease to be relevant, as international and national aspects of the protection of the rights of persons with disabilities need to be rethought and re-evaluated in the face of global change in the world.

\subsection{Features of Employment and Dismissal of Persons with Disabilities under the Legislation of Ukraine}

One of the main measures for solving the problems of employment of persons with disabilities in Ukraine is to establish quotas for the employment of persons with disabilities ${ }^{18}$. In Ukraine, a quota for workplaces for persons with disabilities has existed since 1991 with the adoption of the Law of Ukraine "On the Fundamentals of Social Security of Persons with Disabilities in Ukraine" of March 21, 1991.

Some employers find it difficult to comply with the employment standard for persons with disabilities. The reason is that it is problematic to find such persons to work "as healthy" and still have to comply with the norm. In our opinion, it is necessary to pay attention to which workplace at the enterprise it is possible to employ persons with disabilities. After all, there may be work that an employee will be able to perform, working from home, in comfortable conditions. Because today the Internet offers unlimited possibilities. In addition, we believe that the labels "person with disabilities", "Chernobyl victim", "single mother" and the like should not be put. First of all, it should be evaluated experience, skills, knowledge, and most importantly, the desire to work.

Recognizing its responsibility to persons with disabilities and assuming that these persons have certain health problems that prevent them from actually working on equal terms with other workers, the state establishes certain features of legal regulation of labor in this category of population. Thus, according to part 3 of Article 18 of the Law of Ukraine "On the basics of social protection of persons with disabilities in Ukraine" of March 21, 1991, enterprises, institutions, organizations, natural persons who use hired labor are obliged to allocate and create workers places for employment of persons with disabilities, including special jobs, create working conditions for persons with individual rehabilitation programs and provide other socio-economic guarantees according to the current legislation, and report to the Fund of social protection of persons with disabilities on employment of persons with disabilities.

According to Ukrainian legislation, special workplaces may be created for persons with disabilities. The guarantee of creating a workplace for persons with disabilities is not only its compliance with the requirements and certification of the workplace by a special commission, but also the real employment of a person with a disability in that workplace. We believe that promising labor legislation should clearly stipulate a similar norm.

According to Article 18 of the Law of Ukraine "On the basics of social protection of persons with disabilities in Ukraine" of March 21, 1991, the selection of a job is carried out mainly at the enterprise where the disability was obtained, taking into account the wishes of the person with disability, his or her professional skills and knowledge and recommendations of medical and social expertise. In addition, Article 19 of the Law of Ukraine "On the basics of social protection of persons with disabilities in Ukraine" of March 21, 1991 provides that enterprises, institutions, organizations, must hire persons with disabilities in the amount of $4 \%$ from the average number of full-time employees, and if the organization includes from 8 to 25 people, there should work at least one person with disabilities. Thus, in Ukraine, at the legislative level, there is a quota to be fulfilled by employers when hiring people with disabilities. This provision significantly increases the level of legal protection of persons with disabilities in the field of employment. It should be noted that companies should not be exempted from liability for non-compliance with the standard of jobs intended for employment of persons with disabilities, as they must carry out such employment independently. In addition, according to Ukrainian law, the workplace of a person with a disability (ordinary or specialized) must match his or her individual disability-related functionality.

It should be noted that the quota system has one significant drawback - the state is in fact eliminating the problem of employment of persons with disabilities, placing all its weight on the shoulders of employers. Thus, $\mathrm{O}$. Yaroshenko in one of his scientific works notes that the state's attempt to solve complex social issues at the expense of employers, without making its own extra efforts, often provokes a negative reaction from the last. As a result, they become victims of employment through the quota of persons with disabilities, who are exposed to various forms of discrimination in their workplaces, down to outrageous abuse, reproach and humiliation. Particularly illustrative is the situation in Ukraine, where entrepreneurs, taking persons with disabilities from the quota, pay them a minimum wage and do not actually allow them to work. In such cases, neither professional nor

\footnotetext{
${ }_{18}$ Perez J. (2019). Basic income and the right of persons with disabilities. Age of Human Rights Journal, 12, p. 1-12. Doi 10.17561/tahrj.n12.1
} 
social nor psychological rehabilitation takes place ${ }^{19}$.

It should be emphasized that the current mechanism of employment of persons with disabilities is imperfect. In our opinion, in order for the quota system to work, the state must share with the employer the economic risks related to such employment ${ }^{20}$ (to finance additional measures for the organization of work of a person taking into account his/her individual disability-related functionalities, to provide basic and additional equipment, technical equipment etc.).

In addition, one of the promising directions of employment of this category of population in the current conditions is the development of self-employment. Today, the state should create a more favorable socio-economic climate for persons with disabilities - entrepreneurs (to provide the possibility of obtaining a preferential loan for organizing their own business; to provide preferential taxation; to organize free education of future entrepreneurs; to provide information and free counseling to persons with disabilities who want to launch their own business).

One of the effective means of providing access for persons with disabilities to work is the obligation for employers who use the work of this category of persons to create working conditions for them, taking into account individual rehabilitation programs. It should be noted that an individual program of rehabilitation of a person with a disability is a complex of optimal types, forms, volumes, terms of rehabilitation measures with determination of the order, place of their realization, aimed at restoration and compensation of impaired or lost functions of the body and abilities of the persons with disabilities. It is developed for each person with disability separately on the basis of the National Standard Program of Rehabilitation of Persons with Disabilities No. 886 of December 8, $2006^{21}$.

The labor law of Ukraine establishes a number of guarantees for persons with disabilities when hiring, working, transferring them, and protecting labor as well as terminating an employment contract. In particular, among the guarantees of labor protection for persons with disabilities should be noted the prohibition of their involvement in overtime and night work without their consent. But even with such consent, it is forbidden to involve persons with disabilities in overtime and night work, if this is contrary to the recommendations of the medical and social expert commission. In terms of vacation time, persons with disabilities have certain advantages over other categories of workers (Article 6 of the Law of Ukraine "On Leave" of November 15, 1996). In addition, for persons with disabilities who are sent to work in accordance with the recommendation of medical and social expertise, the test for hiring is not installed (Part 3 of Article 26 of the Labor Code of Ukraine). This provision of national labor law establishes an even higher level of labor rights guarantees than in some developed European countries. For example, in France, it is possible to set up a hiring test, but when refusing to hire a person with disabilities who has not passed the exam, you must inform the labor inspection, which should check the validity of the person's inability to take the job as one who failed the exam ${ }^{22}$.

Today there is an urgent need to strengthen state oversight and employers' compliance with the employment quota for persons with disabilities and to ensure the proper working conditions of the specified category of persons. Some scholars are working on this problem, in particular, Sobol Ye.Yu. emphasizes that the legislation of Ukraine does not contain the definition of "discrimination on the basis of disability", as well as a comprehensive definition of disability, which complicates both the decision of the subject of administrative relations in the protection of the rights and freedoms of persons with disabilities, and prosecution of perpetrators of responsibility for violation of rights and freedoms of persons with disabilities. The scientist proposes to amend the Law of Ukraine "On the Principles of Prevention and Combating Discrimination in Ukraine" of October 14, 2014, in particular, to consolidate the definition of "disability discrimination" in accordance with the definition given in the Convention on the Rights of Persons with Disabilities ${ }^{23}$. In our opinion, such an approach could really improve the protection of people with disabilities.

In Ukraine, dismissal of employees due to disability is prohibited by law. After all, the fact of establishing

\footnotetext{
${ }^{19}$ Yaroshenko O. (2004). Employment of disabled people: differentiation and problems of legal regulation. Bulletin of the Academy of Law Sciences, 3, p. 97-105.

${ }^{20}$ Do Carmo J. (2018). Law of Quotas for People with Disabilities - The Brazilian Experience. Conference on The Right to Work for Persons with Disabilities - International Perspectives, Mar 08-10, p. 307-309.

${ }^{21}$ Cabinet of Ministers of Ukraine (2006). On approval of the National Model Program for the Rehabilitation of Persons with Disabilities: Decree of the Cabinet of Ministers of Ukraine of December 8, 2006 No. 1686. Official Bulletin of Ukraine. 2006. №50. Art.3311.

${ }^{22}$ Kiselev I.Ya. (1998). Foreign labor law. Textbook for high schools. Moscow: NORMA - INFRA Publishing Group, 1998 , p. 80.

${ }^{23}$ Sobol Ye.Yu. (2017). Review of specific provisions of anti-discrimination legislation in foreign countries in the context of violations of the rights of persons with disabilities. Actual Problems of Domestic Jurisprudence, 1 (1), p. 56-60.
} 
disability cannot be a reason for dismissal of an employee on the basis of paragraph 2 of Art. 40 of the Labor Code of Ukraine. It should be noted that the procedure of termination of an employment contract on the basis of paragraph 2 of Art. 40 of the Labor Code of Ukraine has certain nuances, which the employer should not only know but also apply. First of all, the employer must justify the "legitimacy" of dismissing an employee who has a disability on the basis of paragraph 2 of Art. 40 of the Labor Code of Ukraine, because the employee can appeal against the decision of the employer in court. This is why, at a minimum, the employer must collect written evidence that the company did not have any positions that the employee with a disability may hold in accordance with the recommendations of the Medical and Social Expert Commission (hereinafter - MSEC). Accordingly, the employee must be informed. At the same time, the employer may seek clarification from the MSEC, which has established disability and provided work recommendations. If the commission confirms that the worker with disability is indeed unable to perform certain work, the employer must include in his decision the explanation of the commission.

It should be noted that the responsibility for determining the state of working capacity in general and the degree of loss of professional capacity rests with MSEC. The procedure for determining the state of working capacity is governed by the Resolution of the Cabinet of Ministers of Ukraine No. 1317 "Issues of Medical and Social Expertise" of December 3, 2009. Based on the results of the inspection, MSEC issues to a person who is recognized as a person with a disability a certificate of the established form indicating the disability group and an individual rehabilitation program. According to Art. 6 of the Resolution of the Cabinet of Ministers of Ukraine №1317 the conclusions of the commission, rehabilitation measures, defined in the individual program of rehabilitation of the person with disability, are obligatory for the enterprises where the person is employed ${ }^{24}$. These documents confirm the disability and provide the employee with the disability and his employer with certain privileges, rights and obligations under the current legislation, so a person with a disability must be obliged to provide them when applying for a job.

Scholars have repeatedly raised the question: is the employer entitled to transfer a person with a disability who, according to the recommendations of the MSEC, needs to be transferred to another permanent job in case the person with a disability is not satisfied with the employer's offer regarding the nature of work, the amount of pay, etc.? Thus, M.Y. Fluster claims that regardless of the desire of the person with disability, he or she can not be left on previous work if it is contraindicated ${ }^{25}$. We believe that in this case, the employer cannot leave the employee for the previous job, which, according to the conclusion of MSEC, is contraindicated to him or her because of his or her state of health, and if the employee does not agree to be transferred, it would be a reason to release such employee. Thus, according to Part 3 of Article 9 of the Law of Ukraine "On Occupational Safety" of October 14, 1992, the place of work and the average salary are retained for employees who have lost their ability to work due to an accident at work or an occupational disease for the whole period before the restoration of capacity or the establishment of a permanent loss of professional capacity. If the victim is unable to complete his previous work, his training and retraining, as well as employment in accordance with medical recommendations, shall be conducted $^{26}$.

It should be noted that the dismissal of a person with a disability is permitted in cases when, according to the MSEC, the health condition impedes the performance of professional duties or the continuation of work may lead to a deterioration of the health of such employee. In case an employee has a disability, the employer should take into account the MSEC guidelines on the conditions and nature of work for that employee. In addition to these findings, in accordance with Part 1 of Article 17 of the Law of Ukraine "On the basics of social protection of persons with disabilities in Ukraine" of March 21, 1991, individual rehabilitation programs should also be taken into account.

The employer is obliged to comply with the request of the MSEC if the commission concludes that a person with a disability can perform part-time work in accordance with the requirements of Art.172 of the Labor Code of Ukraine. Usually, the MSEC recommends transferring an employee to an easier job. The employer is obliged to fulfill this condition in accordance with Art. 170 of the Labor Code of Ukraine. If it is possible to set the terms of "easier work" within the position occupied by the employee, then he or she is offered to remain in it. If not, the employer selects vacant positions and offers them to an employee with disability. Again, the transfer of an

\footnotetext{
${ }^{24}$ Cabinet of Ministers of Ukraine. (2009). Issues of medical and social expertise: Resolution of the Cabinet of Ministers of Ukraine of December 03, 2009 №1317. Official Bulletin of Ukraine. 2009. № 95. Art. 3265.

${ }^{25}$ Flyaster M.I. (1968). Labor rights of persons with disabilities. Moscow: Legal literature, 1968, p. 156.

${ }^{26}$ Verkhovna Rada of Ukraine. (2003). On Labor Protection: Law of Ukraine of October 14, 1992 No. 2694-XII. Vidomosti of the Verkhovna Rada of Ukraine. 2003. №2. Art.10.
} 
employee to an easier job is possible only with his or her consent.

The employer, unlike the employee, is deprived of the right to terminate the employment contract concluded for an indefinite period with no specific reasons. The right of an employer to terminate the employment contract is more restricted than the same right of an employee. The owner has the right to dismiss the employee on his or her own initiative only in cases specified by law. One of these is the basis provided for in paragraph 1 of Art. 40 of the Labor Code of Ukraine, which gives the employer the opportunity to terminate the employment contract in case of changes in the organization of production. Among such changes in paragraph 1 of Art. 40 of the Labor Code of Ukraine are mentioned: liquidation, reorganization, bankruptcy or re-profiling of an enterprise, institution, organization, reduction in the number of workers.

When released under paragraph 1 of Art. 40 of the Labor Code of Ukraine the rules of Art. 42 of the Labor Code of Ukraine, which establish a pre-emptive right to stay at work should be taken into account. First and foremost, priority is given to employees with higher qualifications and productivity. Thus, paragraph 2 of Article 42 of the Labor Code of Ukraine establishes the list of persons who, under equal conditions of labor productivity and qualification, get priority in staying at work. This category includes: persons with disabilities as a result of the war and workers who have been injured at work or have an occupational disease. In addition, according to paragraph 7 of Art. 20 of the Law of Ukraine "On the Status and Social Protection of Citizens Affected by the Chornobyl Disaster" of February 28, 1991 a similar right is granted to persons who have suffered as a result of the Chornobyl disaster ${ }^{27}$.

It should be noted that the law provides that in case of wrongful dismissal, the employer is liable. First of all, the employer is fined for violation of labor $\mathrm{law}^{28}$. In addition, the legislation stipulates that violations of the labor rights of citizens, including through discrimination on the basis of disability, may be the basis for initiating criminal proceedings. If the court establishes the fact of unlawful dismissal, all funds that the person has not received, should be paid by the employer in favor of the employee for the whole period when he or she was illegally dismissed.

\section{Conclusions}

Summarizing the above, it can be concluded that any person with disability has the right to work, and the determination of disability cannot be a ground for dismissal. Undoubtedly, the determination of disability indicates the limitation of the working capacity, but not every disability may result in a mismatch of the employee in the position or job being performed. After all, there are many positions that can be successfully performed by employees with disability. In addition, such employees may perform preliminary work in special conditions.

We believe that in order to increase the level of social and legal protection of persons with disabilities, it is necessary to amend the legislation aimed at ensuring the "adjustment" of workplaces for persons with disabilities, as well as the necessary support for persons with disabilities in the workplace. In our opinion, Art. 42 of the Labor Code of Ukraine "The prevailing right to leave at work when dismissing employees in connection with changes in the organization of production and work" needs to be improved, in particular to extend the prevailing right to leave at work not only to persons with disability as a result of the war, but to all persons with disabilities without any exceptions.

It is worth noting that the recent reforms in Ukraine, as well as the realities of the modern labor market, necessitate the continuous improvement of labor legislation and its implementation mechanisms. We consider it is necessary to develop a separate chapter in the draft Labor Code of Ukraine, which would be devoted to the legal regulation of the work of persons with disabilities. In addition, the definition of the term "person with disability", guarantees for the conclusion of an employment contract, specifics of the employment, transfer to another job, dismissal at the initiative of the employer of persons with disabilities should be fixed.

It also seems appropriate in the labor law to provide not only legislative measures for the preservation of existing jobs, but also to establish a clear ban on reducing the specified category of persons and strengthening the protection of persons with disabilities from dismissal. In addition, it is necessary to provide for the liability of the employer for the non-observance or violation of the labor rights of persons with disabilities.

\footnotetext{
${ }^{27}$ Verkhovna Rada of Ukraine. (1991). On the Status and Social Protection of Citizens Affected by the Chornobyl Disaster: Law of Ukraine of February 28, 1991 No. 796-XII. Vidomosti of the Verkhovna Rada of the USSR. 1991. №16. Art.200.

${ }_{28}$ Balanta-Cobo P., Padilla-Munoz A. (2019). A step beyond direct and indirect discrimination against persons with disability: methodological approach to discrimination from the intersectional perspective. Age of Human Rights Journal, 13, p. 99-124. Doi 10.17561/tahrj.n13.6
} 


\section{References}

Akpulat, A. (2019). The Liability of the Employer to Employ Disabled Employee. Istanbul Hukuk Mecmuasi, $77(2), 523-553$

Balanta-Cobo, P., \& Padilla-Munoz, A. (2019). A step beyond direct and indirect discrimination against persons with disability: methodological approach to discrimination from the intersectional perspective. Age of Human Rights Journal, 13, 99-124. https://doi.org/10.17561/tahrj.n13.6

Cabinet of Ministers of Ukraine. (2006). On approval of the National Model Program for the Rehabilitation of Persons with Disabilities: Decree of the Cabinet of Ministers of Ukraine of December 8, 2006 No. 1686. Official Bulletin of Ukraine. 2006. №50. Art.3311.

Cabinet of Ministers of Ukraine. (2009). Issues of medical and social expertise: Resolution of the Cabinet of Ministers of Ukraine of December 03, 2009 №1317. Official Bulletin of Ukraine. 2009. № 95. Art. 3265.

Council of Europe. (1996). European Social Charter (Revised). Retrieved May 10, 2020, from https://rm.coe.int/168007cf93

Disability Statistics: Information, Charts, Graphs and Tables. (2020). Retrieved April 10, 2020, from https:/www.disabled-world.com/disability/statistics/

Do Carmo, J. (2018). Law of Quotas for People with Disabilities - The Brazilian Experience. Conference on The Right to Work for Persons with Disabilities - International Perspectives, Mar 08-10, p. $307-309$. https://doi.org/10.5771/9783845291673-306

Flyaster, M. I. (1968). Labor rights of persons with disabilities. Moscow: Legal literature, p. 156.

History of United Nations and Persons with Disabilities - The World Programme of Action Concerning Disabled Persons. $\quad$ (2020). $\quad$ Retrieved April $\quad 10, \quad 2020, \quad$ from https://www.un.org/development/desa/disabilities/history-of-united-nations-and-persons-with-disabilities-th e-world-programme-of-action-concerning-disabled-persons.html

Kasinskaite-Buddeberg, I. (2011). Accessibility policies and the work of UNESCO. Retrieved April 10, 2020, from https:/www.european-agency.org/sites/default/files/UNESCO-Irmgarda-Kasinskaite-Buddeberg.pdf

Kiselev, I. Ya. (1998). Foreign labor law. Textbook for high schools. Moscow: NORMA - INFRA Publishing Group, p. 80.

Perez J. (2019). Basic income and the right of persons with disabilities. Age of Human Rights Journal, $12,1-12$. https://doi.org/10.17561/tahrj.n12.1

President of Ukraine. (2019). Decree of the President of Ukraine "On Improving the Effectiveness of Measures in the Field of Rights of Persons with Disabilities” of 03.12.2019 №875 / 2019. Retrieved April 10, 2020, from https://www.president.gov.ua/documents/8752019-30781

Revillard, A. (2019). Realizing the Right to Access in France: Between Implementation and Activation. Law \& Society Review, 53(4), 950-982. https://doi.org/10.1111/lasr.12434

Saunders, H. (2019). The Invisible Law of Visible Difference: Disfigurement in the Workplace. Industrial Law Journal, 48(4), 487-514. https://doi.org/10.1093/indlaw/dwy019

Sobol, Y. Y. (2017). Review of specific provisions of anti-discrimination legislation in foreign countries in the context of violations of the rights of persons with disabilities. Actual Problems of Domestic Jurisprudence, $1(1), 56-60$.

United Nations General Assembly. (1969). Declaration on Social Progress and Development. Retrieved April 10, 2020, from https://www.ohchr.org/Documents/ProfessionalInterest/progress.pdf

United Nations General Assembly. (1975). Declaration on the Rights of Disabled Persons. Retrieved April 10, 2020, from: https://www.ohchr.org/EN/ProfessionalInterest/Pages/RightsOfDisabledPersons.aspx

United Nations General Assembly. (1993). Standard Rules on the Equalization of Opportunities for Persons with Disabilities. $\quad$ Retrieved April $\quad 10, \quad 2020, \quad$ from https://www.un.org/development/desa/disabilities/standard-rules-on-the-equalization-of-opportunities-for-p ersons-with-disabilities.html

United Nations General Assembly. (2006). Convention on the Rights of Persons with Disabilities and the Optional $\begin{array}{llllll}\text { Protocol thereto } & \text { Retrieved } & \text { April } & 10, & 2020, & \text { from }\end{array}$ https:/www.refworld.org/topic,50ffbce51b1,50ffbce51c9,,0,UNGA,,.html 
United Nations. (1948). Universal Declaration of Human Rights. Retrieved April 10, 2020, from https://www.un.org/en/universal-declaration-human-rights/

Verkhovna Rada of Ukraine. (1971). Labor Code of Ukraine adopted on December 10, 1971. Vidomosti of the Verkhovna Rada of Ukraine. Application to №50. Art. 375.

Verkhovna Rada of Ukraine. (1991). On the basics of social protection for persons with disabilities in Ukraine: Law of Ukraine of March 21, 1991 No. 875-XII. Vidomosti of the Verkhovna Rada of the USSR. 1991. №21. Art.252.]

Verkhovna Rada of Ukraine. (1991). On the Status and Social Protection of Citizens Affected by the Chornobyl Disaster: Law of Ukraine of February 28, 1991 No. 796-XII. Vidomosti of the Verkhovna Rada of the USSR. 1991. №16. Art.200.

Verkhovna Rada of Ukraine. (2003). On Labor Protection: Law of Ukraine of October 14, 1992 No. 2694-XII. Vidomosti of the Verkhovna Rada of Ukraine. 2003. №2. Art.10.

Verkhovna Rada of Ukraine. (2006). On the rehabilitation of persons with disabilities in Ukraine: Law of Ukraine of October 6, 2005 No. 2961-IV. Vidomosti of the Verkhovna Rada of Ukraine. 2006. №2. Art.36.

World Health Organization. (1980). International Classification of Impairments, Disabilities and Handicaps. Retrieved April 10, 2020, from https://apps.who.int/iris/bitstream/handle/10665/41003/9241541261_eng.pdf;jsessionid=9A3E39C13CC6D 0564FAE3176122D770C? sequence $=1$

Yaroshenko, O. (2004). Employment of disabled people: differentiation and problems of legal regulation. Bulletin of the Academy of Law Sciences, 3, 97-105.

\section{Copyrights}

Copyright for this article is retained by the author(s), with first publication rights granted to the journal.

This is an open-access article distributed under the terms and conditions of the Creative Commons Attribution license (http://creativecommons.org/licenses/by/4.0/). 